\title{
Age-Related Alterations in the Behavior and Serotonin-Related Gene mRNA Levels in the Brain of Males and Females of Short-Lived Turquoise Killifish (Nothobranchius furzeri)
}

\author{
Valentina S. Evsiukova ${ }^{1}$, Elizabeth A. Kulikova ${ }^{1}$ and Alexander V. Kulikov ${ }^{2, *(D)}$ \\ 1 Department of Psychoneuropharmacology, Federal Research Center Institute of Cytology and Genetics, \\ Siberian Branch of the Russian Academy of Sciences, 630090 Novosibirsk, Russia; \\ evsiukova@bionet.nsc.ru (V.S.E.); kulikova@bionet.nsc.ru (E.A.K.) \\ 2 Department of Genetic Collections of Neural Disorders, Federal Research Center Institute of Cytology and \\ Genetics, Siberian Branch of the Russian Academy of Sciences, 630090 Novosibirsk, Russia \\ * Correspondence: v_kulikov@bionet.nsc.ru; Tel.: +7-38-3363-6187
}

\section{check for} updates

Citation: Evsiukova, V.S.; Kulikova, E.A.; Kulikov, A.V. Age-Related Alterations in the Behavior and Serotonin-Related Gene mRNA Levels in the Brain of Males and Females of Short-Lived Turquoise Killifish (Nothobranchius furzeri). Biomolecules 2021, 11, 1421. https:// doi.org/10.3390/biom11101421

Academic Editor: Philippe De Deurwaerdère

Received: 30 August 2021 Accepted: 25 September 2021 Published: 28 September 2021

Publisher's Note: MDPI stays neutral with regard to jurisdictional claims in published maps and institutional affiliations.

Copyright: (c) 2021 by the authors. Licensee MDPI, Basel, Switzerland. This article is an open access article distributed under the terms and conditions of the Creative Commons Attribution (CC BY) license (https:// creativecommons.org/licenses/by/ $4.0 /)$.

\begin{abstract}
Short-lived turquoise killifish (Nothobranchius furzeri) have become a popular model organism for neuroscience. In the present paper we study for the first time their behavior in the novel tank diving test and the levels of mRNA of various 5-HT-related genes in brains of 2-, 4- and 6-month-old males and females of $N$. furzeri. The marked effect of age on body mass, locomotor activity and the mRNA level of Tph1b, Tph2, Slc6a4b, Mao, Htr1aa, Htr2a, Htr3a, Htr3b, Htr4, Htr6 genes in the brains of $N$. furzeri males was shown. Locomotor activity and expression of the Mao gene increased, while expression of Tph1b, Tph2, Slc6a4b, Htr1aa, Htr2a, Htr3a, Htr3b, Htr4, Htr6 genes decreased in 6-month-old killifish. Significant effects of sex on body mass as well as on mRNA level of Tph1a, Tph1b, Tph2, Slc6a4b, Htr1aa, 5-HT2a, Htr3a, Htr3b, Htr4, and Htr6 genes were revealed: in general both the body mass and the expression of these genes were higher in males. N. furzeri is a suitable model with which to study the fundamental problems of age-related alterations in various mRNA levels related with the brains 5-HT system.
\end{abstract}

Keywords: turquoise killifish; aging; sexual dimorphism; novel tank diving test; tryptophan hydroxylase; monoamine oxidase; serotonin transporter; serotonin receptors; gene expression; brain

\section{Introduction}

The brain's serotonin (5-HT) system plays a key role in the regulation of neuronal plasticity [1], numerous physiological functions and various kinds of behavior [2]. Its dysfunctions are associated with psychopathologies such as depression, anxiety, obsessivecompulsive syndrome, etc [3-7].

Age-related alterations in the brain's 5-HT system frequently accompany psychic disorders in senior patients [8]. The majority of knowledge concerning age-related changes in the brain's 5-HT system was based on results obtained from aged people (60 years old or older) using the PET assay and post mortem studies as well as experiments carried out on laboratory monkeys and rodents (see reviews) [9-11]. However, these studies are dramatically limited due to ethical norms and the relatively long lifespan of laboratory monkeys ( $>20$ years old) and rodents ( 2 years old).

The short-lived turquoise killifish, Nothobranchius furzeri, inhabits ephemeral ponds in southeastern Africa. It's fertilized eggs survive the dry season in diapause. The larvae hatch immediately after the pond is filled with water, grow rapidly, reach sexual maturity within four to six weeks, continuously mate and spawn during the wet season, and die at the age of six to eight months [12-14]. Six- to eight-month-old N. furzeri show morphological and behavioral hallmarks of aging, such as reduced coloration in males, emaciation, spinal curvature, spine and face malformations [12,14], reduced spontaneous, exploratory activities [15] and impaired learning performance [16,17]. 
The brain's 5-HT system regulates the physiological functions and behavior of killifish. Indeed, chronic treatment with small doses of the 5-HT transporter blocker, fluoxetine, led to decreased body size, as well as increased fecundity and sociability in $N$. furzeri $[18,19]$. However, until now there was only one publication revealing no effect of sex and rearing conditions on the level and turnover of 5-HT in brains of 108-day-old N. furzeri [20]. The fish brain's 5-HT system is homologous to that of mammals [21]. The fast life-cycle, hallmarks of aging and possible homology of $N$. furzeri make this species a convenient model to elucidate the alterations in the brain's 5-HT system and 5-HT-related functions in aging.

The novel tank diving test is the most frequently used test to demonstrate the conflict between exploration and anxiety in zebrafish (Danio rerio) [22,23]. 5-HT seems to regulate zebrafish's reaction to novelty [24].

The aim of the present study was to investigate age-dependent alterations in the 5-HT dependent behavior and mRNA levels of the 5-HT-related genes encoding the key enzymes of metabolism, transporter and receptors of 5-HT in the brain of N. furzeri. This approach provides complex information about the alterations in the brain's 5-HT system activity in killifish during aging. Here we intended to compare the locomotor activity and anxiety-related behavior in the novel tank diving test as well as mRNA levels of all sequenced 5-HT-related genes such as Tph1a, Tph1b, Tph2, Slc6a4b, Mao, Htr1aa, Htr1b, Htr1f, Htr2a, Htr2cl1, Htr3a, Htr3b, Htr4, Htr5ab, Htr6, and Htr7 in brains of 2-, 4- and 6-month-old males and females of $N$. furzeri.

\section{Materials and Methods}

\subsection{Animals}

The experiments were carried out on 37 males and 27 females of $N$. furzeri of the ZMZ1001 strain. The progenitors of these killifish were received from the European Research Institute of Biology of Ageing (ERIBA, Groningen, Netherlands) [20]. The breeding and hatching of these fish were carried out in the fish facility of the Institute of Cytology and Genetics SB RAS (Novosibirsk, Russia) according to the published protocol [25]. The larvae were fed ad libitum three times per day with freshly hatched brine shrimps (Artemia salina) for the first three weeks after hatching. At the age of 21 days, post-hatch young fish were reared in mixed-sex groups in 125 L glass tanks $(75 \mathrm{~cm}$ in length, $40 \mathrm{~cm}$ in depth, $48 \mathrm{~cm}$ in width, water depth was $35 \mathrm{~cm}$ ). The sizes of these groups changed from 30 at the beginning to 15 at the end of experiment. Water in the tanks was constantly filtered and aerated with a filter, a model XL-860 (Xilong, Zhongshan, China), and its temperature was $27 \pm 1^{\circ} \mathrm{C}$. Tanks were equipped with three plastic plants $14 \mathrm{~cm}$ in height each and two dishes $(10 \mathrm{~cm}$ in diameter, $3 \mathrm{~cm}$ in height) filled with sand for spawning. The plastic plants served as environmental enrichment and as shelters from aggressive conspecifics. Every day (at 17:00) the tanks were cleaned and $10 \%$ of the water was substituted with tap water filtered through the expert hard filter Barrier Expert Standard (BVT Barrier Rus, Noginsk, Russia). The $12 \mathrm{~h}$ light/12 h dark ("light on" mode at 09:00) photoperiod was maintained. Young and adult killifish were fed until satiation two times per day with frozen blood worms (Chironomus plumosus). To avoid competition for food, we added as many worms as the fish could eat in an hour. The fish were kept in these tanks until the novel tank diving test.

There were three age groups of killifish: 60 days old (13 males and 8 females), 120 days old (12 males and 11 females) and 180 days old (12 males and 8 females). Each group consisted of males and females caught randomly from the tanks.

\subsection{Novel Tank Diving Test}

When we started carrying out the test, the age of males and females was 60, 120 and 180 days. The test was conducted in the daytime (11:00 a.m.-3:00 p.m.) in a glass test tank ( $24 \mathrm{~cm}$ in length, $15 \mathrm{~cm}$ in depth and $7 \mathrm{~cm}$ in width) according to the published protocol [20]. The fish were individually transferred from their home tank into the test one and the recording started immediately. The water column $(24 \mathrm{~cm}$ in length and 
$10 \mathrm{~cm}$ in depth) was virtually divided into the lower, middle and upper thirds $(24 \mathrm{~cm}$ in length and $3.3 \mathrm{~cm}$ in height each). The test duration was $5 \mathrm{~min}$. The fish position was automatically recorded for $5 \mathrm{~min}$ at rate of $30 \mathrm{fps}$ by a C920 Pro HD Web camera (Logitech, Lausanne, Switzerland) connected to a computer (Windows 7) via a USB 2.0 port. The stream of frames was automatically analyzed in real-time by the EthoStudio software (Institute of Automation and Electrometry, Siberian Branch of Russian Academy of Sciences, Novosibirsk, Russia) [26] and saved on a hard disk as a compressed video file. The EthoStudio software separated the pixels associated with the fish from those associated with the background frame by frame, applying the threshold algorithm, [26] and calculated the coordinates of the fish center. Moreover, the EthoStudio software automatically calculated the density map corresponding to the spatial distribution of fishassociated pixels in the tank $[26,27]$. The sequence of coordinates and the density map were used to evaluate (1) the distance travelled (cm); (2) the immobility time (\%); (3) the mean distance from the tank's bottom (cm); the time spent (\%) in (4) the lower and (5) the upper thirds of the tank,; and(6) the explored part of the tank (\%). The fourth and fifth parameters were calculated as the ratios of the amount of fish-associated pixels in the lower and upper thirds of the tank, respectively, to the sum of fish-associated pixels in all three thirds $[18,26,27]$. The last parameter was calculated as the ratio of the amount of pixels visited by the fish to the total amount of pixels in the tank's water area [28]. Each fish was recorded only once.

\section{3. $q P C R$}

Immediately after the novel tank diving test the fish were euthanized by immersion into $0.1 \%$ tricaine methanesulfonate (Sigma-Aldrich, St. Louis, MO, USA) solution and then into cold water $(+2 \mathrm{C})$, their bodies were immediately dried with dry napkins and their masses were measured using an Ohaus PA-512 electronic balance (Ohaus Corporation, Parsippany, USA) with an accuracy of $10 \mathrm{mg}$. Then their whole brains were immediately removed, frozen with liquid nitrogen and stored at $-80{ }^{\circ} \mathrm{C}$ [20]. Because of the small size of the brain, the method sensitivity and fish numbers, we could reliably quantify the gene expression only in the whole brain. The brain was homogenized in $300 \mu \mathrm{L}$ of Trizol reagent (Bio Rad, Hercules, CA, USA) using a motor-driven grinder (Z359971, SigmaAldrich, St. Louis, MO, USA). Total mRNA extraction; treatment of RNA with RNAase free DNAase (Promega, Madison, WI, USA); cDNA synthesis with a random hexanucleotide primer and R01 Kit (Biolabmix, Novosibirsk, Russia) and SYBR Green real-time quantitative PCR with selective primers (Table 1) and R401 Kit (Sintol, Moscow, Russia) were performed according to the manufacturers' protocols. RNA quality was checked by electrophoresis in $1 \%$ agarose. Only the RNA samples with two clear bands of ribosomal RNA were used for the qPCR study. The primer pairs' design was based on the published sequences of the target genes (https: / / www.ensembl.org/index.html (accessed on 30 August 2021)). As for the external standards, we used solutions containing 50, 100, 200, 400, 800, 1600, 3200,6400 and 12,800 copies of genomic DNA extracted from killifish muscle. The gene expression was presented as a relative number of cDNA copies calculated on 100 copies of Polr2eb cDNA as internal standard $[29,30]$.

\subsection{Statistics}

All data were tested using Kolmogorov's test and met the assumption of normality. Data were presented as the mean \pm SEM and analyzed by two-way ANOVA with "Age" and "Sex", including their interaction, as the independent factors. Post hoc analyses were carried out using the Fisher's LSD multiple comparison test when appropriate. In addition, the number of variables was reduced through principal component analysis with factor varimax normalized rotation using Statistics 8.0 (StatSoft, Inc, Tulsa, OK, USA). For principal component analysis, the values of immobility time, explored part of the tank, time spent in the lower and upper thirds of the tank were transformed by square root extraction. Then the factors were analyzed through discriminant analysis. Statistical 
significance was set at $p<0.05$. The significance of correlation coefficients was corrected according to Bonferroni.

Table 1. Sequences and annealing temperatures of the primers.

\begin{tabular}{|c|c|c|}
\hline Gene & Primer Sequences & Annealing Temperatures, ${ }^{\circ} \mathrm{C}$ \\
\hline Polr2e & $\begin{array}{l}\text { F 5 } 5^{\prime} \text {-ctgtgccatgatcgaggttac-3' } \\
\text { R 5'-gacgaccttcgctcggttt-3' }\end{array}$ & 64 \\
\hline Tph1a & $\begin{array}{l}\text { F } 5^{\prime} \text {-agtttgccaagaccatcaag- } 3^{\prime} \\
\text { R } 5^{\prime} \text {-cttgttgagccgattgagag- } 3^{\prime}\end{array}$ & 60 \\
\hline Tph1b & $\begin{array}{l}\text { F } 5^{\prime} \text {-agcactcaggtttcagcattc- } 3^{\prime} \\
\text { R } 5^{\prime} \text {-ggctcaggcgtgtaaagagg- } 3^{\prime}\end{array}$ & 63 \\
\hline Tph2 & $\begin{array}{c}\text { F 5'-acgaacgtctttcagtcccatc- } 3^{\prime} \\
\text { R } 5^{\prime} \text {-tggaagagtttgagagctttgacc- } 3^{\prime}\end{array}$ & 64 \\
\hline Mao & $\begin{array}{l}\text { F } 5^{\prime} \text {-ttctcagtaacatgactcaacacttg- } 3^{\prime} \\
\text { R } 5^{\prime} \text {-ttgcttctgtgaactcactgtag- } 3^{\prime}\end{array}$ & 63 \\
\hline Slc6a4b & $\begin{array}{l}\text { F 5'-agacggattccagggacaag-3' } \\
\text { R 5'-cgtttccaagatccactgcg- } 3^{\prime}\end{array}$ & 63 \\
\hline Htr1aa & $\begin{array}{c}\text { F } 5^{\prime} \text {-ggaactttcatcgtgtgctgg- } 3^{\prime} \\
\text { R } 5^{\prime} \text {-gatgggattcaggagagagttgg- } 3^{\prime}\end{array}$ & 64 \\
\hline$H t r 1 b$ & $\begin{array}{c}\mathrm{F} 5^{\prime} \text {-tggtgtccatcctggtaatgc- } 3^{\prime} \\
\mathrm{R} 5^{\prime} \text {-cagtaccgatccaaagcgattac- } 3^{\prime}\end{array}$ & 64 \\
\hline Htr1f & $\begin{array}{l}\text { F } 5^{\prime} \text {-atggatttcttcaactggactgaag- } 3^{\prime} \\
\text { R } 5^{\prime} \text {-cagggagcagatgaggtagtt- } 3^{\prime}\end{array}$ & 63 \\
\hline$H \operatorname{tr} 2 a$ & $\begin{array}{c}\text { F 5'-cctttgttgccttctttgttcc- } 3^{\prime} \\
\text { R } 5^{\prime} \text {-gacaccgaggtttgtggtag- } 3^{\prime}\end{array}$ & 62 \\
\hline Htr2cl1 & $\begin{array}{l}\text { F 5'-tggaccttaacctaacccagc- } 3^{\prime} \\
\text { R 5 } 5^{\prime} \text {-caggaagaagttggtggcatt- } 3^{\prime}\end{array}$ & 63 \\
\hline$H \operatorname{tr} 3 a$ & $\begin{array}{l}\text { F } 5^{\prime} \text {-ttgtacgtctggtccacaagc- } 3^{\prime} \\
\text { R } 5^{\prime} \text {-tgttttccttgtaatgctccaggt- } 3^{\prime}\end{array}$ & 64 \\
\hline$H t r 3 b$ & $\begin{array}{c}\text { F } 5^{\prime} \text {-gttctttgtggtgtgcatggc- } 3^{\prime} \\
\text { R } 5^{\prime} \text {-gatcgagggtttgatggaggtt- } 3^{\prime}\end{array}$ & 64 \\
\hline Htr4 & $\begin{array}{l}\text { F 5'-ccaactatttcatcgtgtccetg- } 3^{\prime} \\
\text { R 5 } 5^{\prime} \text {-gtttcaccgtagatccagttctc-3 } 3^{\prime}\end{array}$ & 63 \\
\hline Htr $5 a b$ & $\begin{array}{l}\text { F } 5^{\prime} \text {-caggtctggatctcatttgacg- } 3^{\prime} \\
\text { R } 5^{\prime} \text {-ctagtcttgagcgtgtactcc-3' }\end{array}$ & 62 \\
\hline Htr6 & $\begin{array}{l}\text { F } 5^{\prime} \text {-ctagaccgttacctcttcatcatc- } 3^{\prime} \\
\text { R } 5^{\prime} \text { - tcaatgggaaggaaagaagcc- } 3^{\prime}\end{array}$ & 62 \\
\hline Htr7 & $\begin{array}{l}\text { F } 5^{\prime} \text {-gtactacaagatattcagggcagc- } 3^{\prime} \\
\text { R } 5^{\prime} \text {-ggagatgtttcttcgctcgc- } 3^{\prime}\end{array}$ & 63 \\
\hline
\end{tabular}

\section{Results}

\subsection{Body Mass of 2, 4 and 6-Month-Old Males and Females of $N$. furzeri}

Marked effects of "Age" $\left(\mathrm{F}_{2,57}=8.73, p=0.0005\right)$, and"Sex" $\left(\mathrm{F}_{1,57}=72.09, p<0.0001\right)$ factors, but not their interaction $\left(\mathrm{F}_{2,57}<1\right)$ on body mass, were revealed. Six-month-old males were heavier than two-month-old ones (Figure 1). However, no difference in body mass between two, four and six-month-old females was shown (Figure 1). Males were heavier than females of the same age (Figure 1).

3.2. Behavior in the Novel Tank Diving Test of Two-, Four-and Six-Month-Old Males and Females of $N$. furzeri

A significant effect of the "Age" factor on distance travelled and mean distance from the tank's bottom was revealed (Table 2). We also observed as a tendency the effect of the "Age" factor on immobility time ( $p=0.052$, Table 2$)$. Four- and six-month-old males did not differ from two-month-old males in distance travelled, mean distance from the tank's bottom and immobility time. At the same time, the distance travelled was higher, while immobility time and mean distance from the tank's bottom were lower in six-month-old fish compared to four-month-old ones (Figure 2). No age-dependent alteration in the explored part of the tank or time spent in the lower and upper thirds of the tank was 
observed in males (Figure 2). Females of all studied age groups did not differ in these traits (Figure 2).

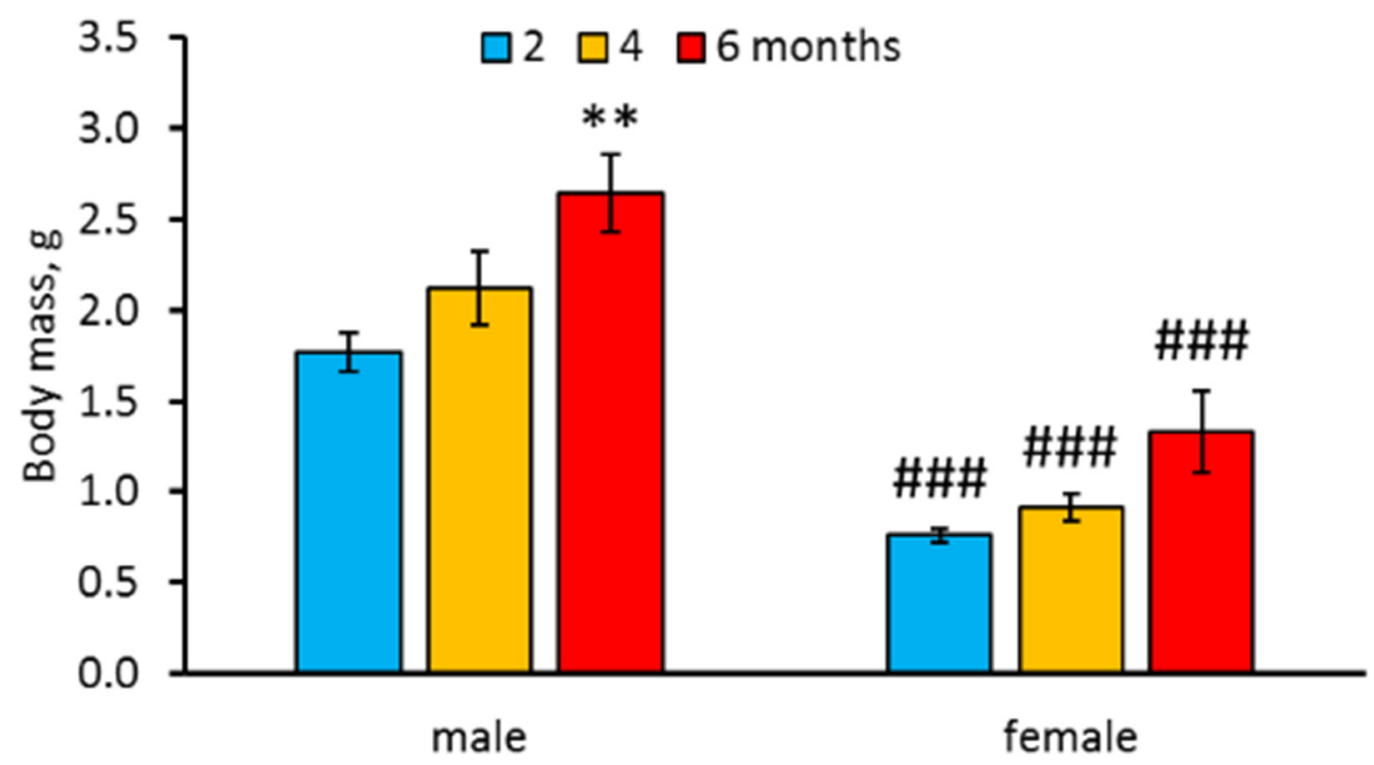

Figure 1. Body mass of two-, four-, and six-month old males and females $N$. furzeri. ${ }^{* *} p<0.01$ vs. two-month-old males, \#\#\# $p<0.001$ vs. males of the same age.

Table 2. Two-way ANOVA of the effect of "Age", "Sex" factors and their interaction on the variability of behavior of $N$. furzeri in the novel tank diving test.

\begin{tabular}{cccc}
\hline Trait & Age & Sex & Interaction \\
\hline Distance traveled, $\mathrm{cm}$ & $\mathbf{F}_{2,58}=\mathbf{3 . 3 9}, \boldsymbol{p}=\mathbf{0 . 0 4}$ & $\mathrm{F}_{1,58}=2.89, p=0.09$ & $\mathrm{~F}_{2,58}<1$ \\
Immobility time, \% & $\mathrm{F}_{2,58}=3.12, p=0.052$ & $\mathbf{F}_{\mathbf{1 , 5 8}}=5.45, p=\mathbf{0 . 0 2}$ & $\mathrm{F}_{2,58}<1$ \\
Explored part, \% & $\mathrm{F}_{2,58}=3.0, p=0.06$ & $\mathrm{~F}_{1,58}=1.74, p=0.19$ & $\mathrm{~F}_{2,58}<1$ \\
Distance from the bottom, cm & $\mathrm{F}_{2,58}=3.22, p=\mathbf{0 . 0 4 7}$ & $\mathrm{F}_{1,58}<1$ & $\mathrm{~F}_{2,58}<1$ \\
Time in the lower third, \% & $\mathrm{F}_{2,58}=2.98, p=0.09$ & $\mathrm{~F}_{1,58}<1$ & $\mathrm{~F}_{2,58}<1$ \\
Time in the upper third, \% & $\mathrm{F}_{2,58}=2.42, p=0.1$ & $\mathrm{~F}_{1,58}<1$ & $\mathrm{~F}_{2,58}<1$ \\
\hline
\end{tabular}
Statistically significant values are marked in bold.

A marked effect of the "Sex" factor on immobility time was shown (Table 2). This trait decreased in four-month-old females compared to males of the same age (Figure 2). Males and females of all age groups did not differ in distance travelled, explored part of the tank, mean distance from the tank's bottom, or in time spent in the lower and upper thirds of the tank (Table 2, Figure 2).

Principal component analysis revealed that $92.7 \%$ of variability of these six behavioral traits in males could be described by two factors. The first factor correlated with the anxietyrelated traits, such as time spent in the lower, upper thirds and mean distance from the tank's bottom. We named it "anxiety". The second factor correlated with locomotion traits such as travelled distance, immobility time and explored part of the tank. We named it "locomotion" (Table 3). The two-factors model revealed significant effect of age on behavior in males $\left(\mathrm{F}_{4,60}=3.13, p=0.021\right)$. Discriminant analysis revealed differences in behavior between four- and six-month-old males $(p=0.0034)$ (Figure 3$)$. No age-dependent alteration in the first factor was observed $\left(\mathrm{F}_{2,30}=2.66, p=0.0 .087\right)$. At the same time, significant age-dependent changes of the second factor were witnessed $\left(\mathrm{F}_{2,30}=4.27, p=0.023\right)$. 
ロ2 $\square 4 \square$ months
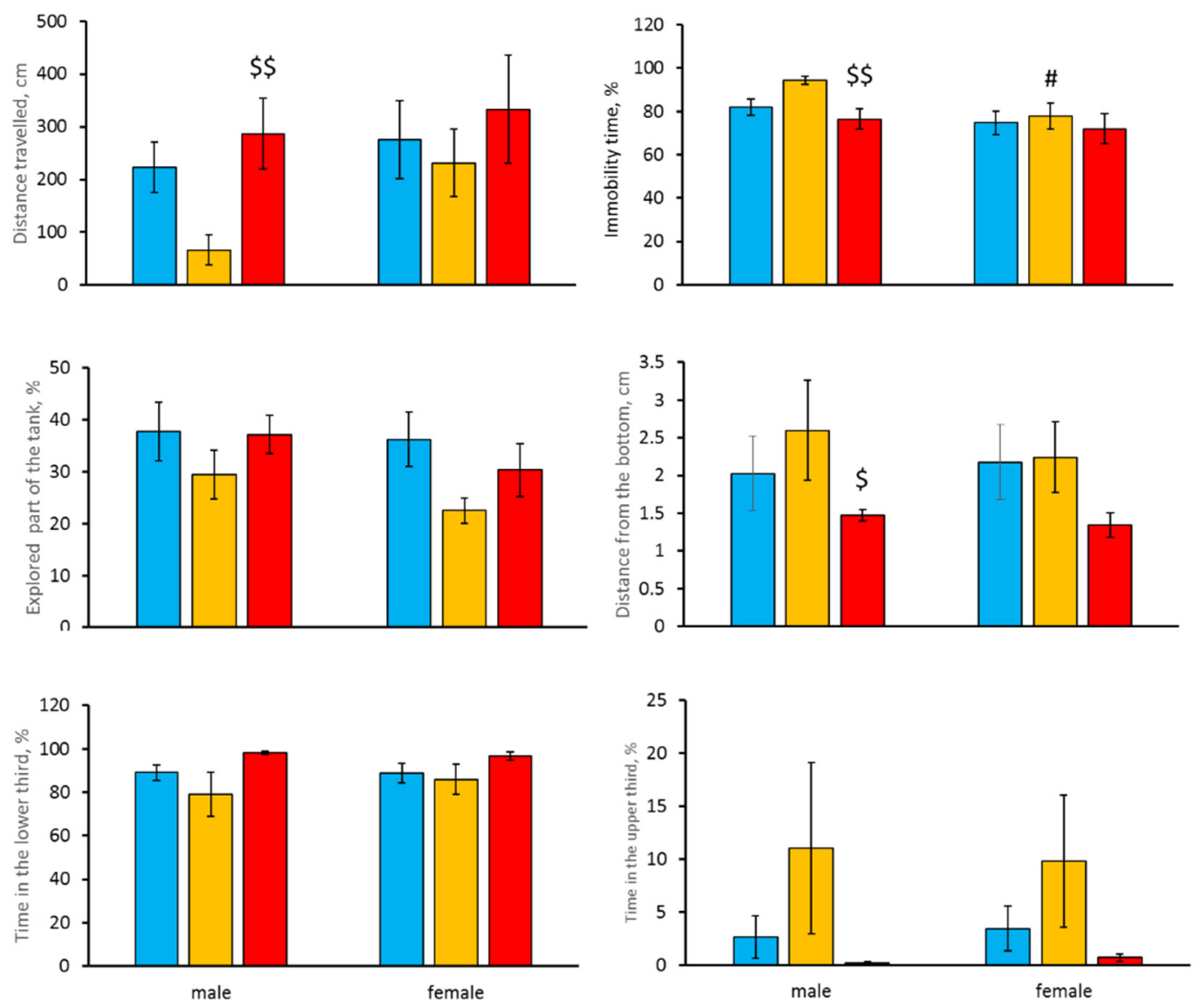

Figure 2. Distance travelled (cm), immobility time (\%), explored part of the tank (\%), mean distance from the tank's bottom $(\mathrm{cm})$, time spent (\%) in the lower and upper third of the tank in the novel tank diving test in two-, four- and six-month-old males and females $N$. furzeri. ${ }^{\$} p<0.05, \$ \$ p<0.01$ vs. four-month-old males, ${ }^{\#} p<0.05$ vs. males of the same age.

Table 3. Factor loadings (correlation coefficients) for travelled distance, immobility time, distance from the tank's bottom, explored part of the tank, time spent in the lower and upper thirds of the tank in two-, four- and six-month-old males of N. furzeri.

\begin{tabular}{|c|c|c|}
\hline Trait & Factor $1(51.9 \%)$ & Factor $2(40.8 \%)$ \\
\hline Distance traveled, cm & $\mathrm{r}=-0.10, p>0.05$ & $r=0.96, p<0.0001$ \\
\hline Immobility time, \% & $\mathrm{r}=0.10, p>0.05$ & $\mathrm{r}=-0.98, p<0.0001$ \\
\hline Explored part, \% & $\mathrm{r}=-0.40, p>0.05$ & $\mathrm{r}=0.78, p<0.001$ \\
\hline Distance from the bottom, $\mathrm{cm}$ & $r=-0.99, p<0.0001$ & $\mathrm{r}=0.05, p>0.05$ \\
\hline Time in the lower third, $\%$ & $\mathrm{r}=0.98, p<0.0001$ & $\mathrm{r}=0.0, p>0.05$ \\
\hline Time in the upper third, $\%$ & $\mathrm{r}=-0.97, p<0.0001$ & $\mathrm{r}=0.0, p>0.05$ \\
\hline
\end{tabular}

Statistically significant values are marked in bold.

3.3. Levels of mRNA of Polr2eb, Tph1a, Tph1b, Tph2, Slc6a4b, Mao, Htr1aa, Htr1b, Htr1f, Htr2a, Htr2cl1, Htr3a, Htr3b, Htr4, Htr5ab, Htr6, and Htr7 Genes in Brain of 2-, 4-, and 6-Month-Old Males and Females of $N$. furzeri

No effect of "Age" or "Sex" factors and their interaction on the mRNA level of Polr2eb gene in the brain of killifish was observed (Table 4). Therefore, we could correctly use this gene mRNA level as an internal standard $[27,28]$. 
- $2 \square 4 \Delta 6$ months of age

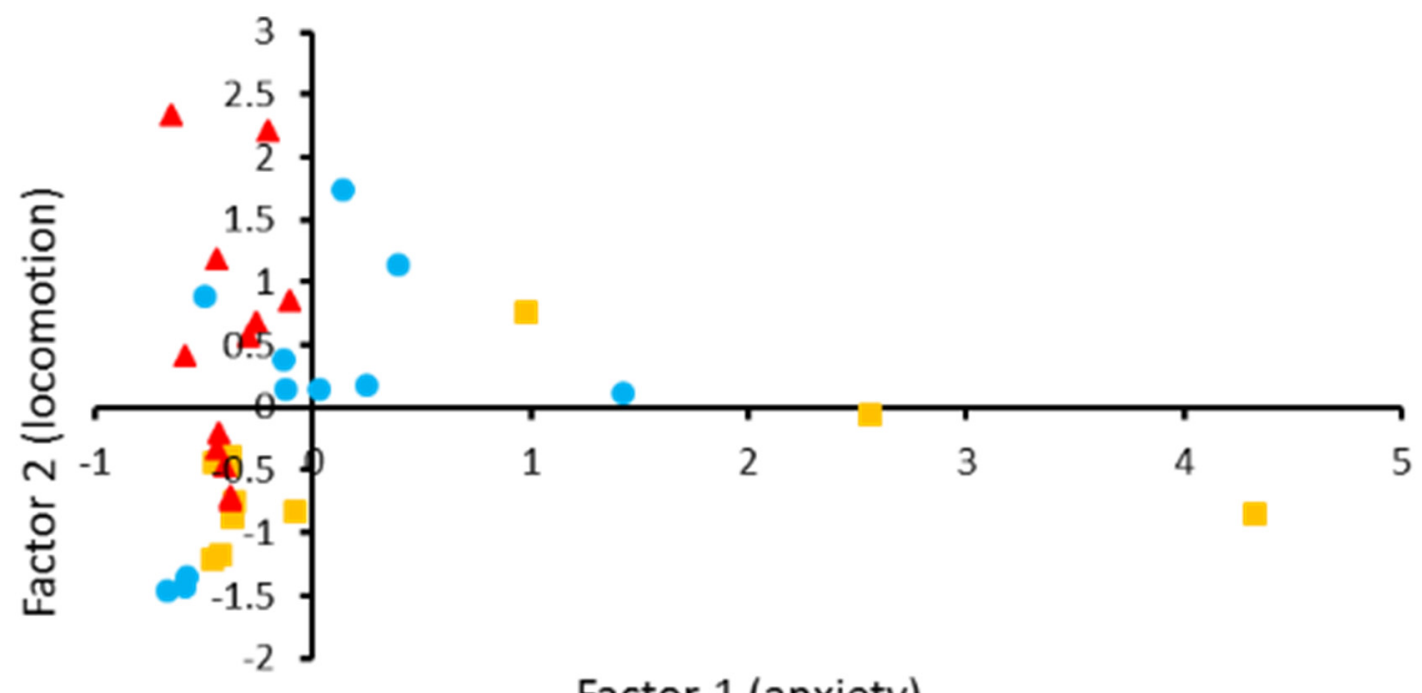

Factor 1 (anxiety)

Figure 3. Individual scores for eleven two-month-old, eleven four-month-old, and twelve six-month-old males of N. furzeri along two factors yielded by the principal component analysis. These factors generalize six behavioral traits in the novel tank diving test. Factor 1 loads the anxiety-related traits such as distance from the tank's bottom and time spent in the lower and upper thirds. Factor 2 loads the traits corresponding to locomotor and exploratory activities such as travelled distance, immobility time and the explored part of the tank. The coordinates of the two axes represent the factor scores of individual animals. Ten of 11 scores corresponding to four-month-old males are located in the lower half of the graphic, while all 12 scores corresponding to six-month-old males are located in the left half of graphic.

Table 4. Two-way ANOVA of the effect of "Age", "Sex" factors and their interaction on the variability of mRNA level of Polr2e, Tph1a, Tph1b, Tph2, Slc6a4b, Mao, Htr1aa, Htr1b, Htr1f, Htr2a, Htr2Cl1, Htr3a, Htr3b, Htr4, Htr5ab, Htr6, and Htr7 genes in the brain of $N$. furzeri.

\begin{tabular}{|c|c|c|c|}
\hline Gene & Age & Sex & Interaction \\
\hline Polr2eb & $\mathrm{F}_{2,54}<1$ & $\mathrm{~F}_{1,54}<1$ & $\mathrm{~F}_{2,54}<1$ \\
\hline Tph1a & $\mathrm{F}_{2,54}<1$ & $\mathrm{~F}_{1,54}=17.38, p<0.001$ & $\mathrm{~F}_{2,54}<1$ \\
\hline Tph1b & $F_{2,54}=3.51, p=0.037$ & $F_{1,54}=24.49, p<0.001$ & $\mathrm{~F}_{2,54}=4.17, p=0.021$ \\
\hline Tph2 & $\mathrm{F}_{2,54}=2.62, p=0.082$ & $\mathrm{~F}_{1,54}=12.45, p<0.001$ & $\mathrm{~F}_{2,54}<1$ \\
\hline Мao & $\mathrm{F}_{2,54}=9.72, p<0.001$ & $\mathrm{~F}_{1,54}=1.54, p=0.219$ & $\mathrm{~F}_{2,54}<1$ \\
\hline Slc6a4b & $F_{2,54}=3.41, p=0.04$ & $\mathrm{~F}_{1,54}=23.57, p<0.001$ & $\mathrm{~F}_{2,54}=5.15, p=0.009$ \\
\hline Htr1aa & $F_{2,54}=15.37, p<0.001$ & $\mathrm{~F}_{1,54}=5.65, p=0.021$ & $F_{2,54}=6.83, p=0.002$ \\
\hline$H \operatorname{tr} 1 b$ & $F_{2,54}=2.38, p=0.101$ & $\mathrm{~F}_{1,54}<1$ & $\mathrm{~F}_{2,54}=1.25, p=0.295$ \\
\hline Htr1f & $\mathrm{F}_{2,54}<1$ & $\mathrm{~F}_{1,54}<1$ & $\mathrm{~F}_{2,54}<1$ \\
\hline$H+r 2 a$ & $\mathrm{~F}_{2,54}=2.98, p<0.059$ & $\mathrm{~F}_{1,54}=5.09, p=0.028$ & $\mathrm{~F}_{2,54}=4.04, p=0.023$ \\
\hline Htr $2 l C 1$ & $\mathrm{~F}_{2,54}=2.15, p=0.126$ & $\mathrm{~F}_{1,54}<1$ & $\mathrm{~F}_{2,54}=1.81, p=0.174$ \\
\hline$H \operatorname{tr} 3 a$ & $\mathrm{~F}_{2,54}=3.54, p=0.036$ & $F_{1,54}=20.36, p<0.001$ & $\mathrm{~F}_{2,54}=4.46, p=0.016$ \\
\hline$H+r 3 b$ & $\mathrm{~F}_{2,54}=4.83, p=0.012$ & $\mathrm{~F}_{1,54}=23.12, p<0.001$ & $\mathrm{~F}_{2,54}=4.37, p=0.017$ \\
\hline Htr4 & $\mathrm{F}_{2,54}=2.93, p=0.062$ & $F_{1,54}=10.58, p=0.002$ & $\mathrm{~F}_{2,54}=3.32, p=0.044$ \\
\hline Htr $5 a b$ & $\mathrm{~F}_{2,54}=1.56, p=0.219$ & $\mathrm{~F}_{1,54}=1.42, p=0.239$ & $\mathrm{~F}_{2,54}=2.89, p=0.064$ \\
\hline Htr6 & $F_{2,54}=5.11, p=0.009$ & $\mathrm{~F}_{1,54}=14.62, p<0.001$ & $\mathrm{~F}_{2,54}=1.86, p=0.166$ \\
\hline Htr7 & $\mathrm{F}_{2,54}=2.25, p=0.116$ & $\mathrm{~F}_{1,54}<1$ & $\mathrm{~F}_{2,54}<1$ \\
\hline
\end{tabular}

Statistically significant values are marked in bold.

Marked effect of the "Age" and "Sex" factors interaction on the mRNA level of Tph1b, Slc6a4b, Htr1aa, Htr2a, Htr3a, Htr3b, and Htr4 genes was shown (Table 4). In addition, a significant effect of the "Age" factor on the mRNA level of Tph1b, Slc6a4b, Mao, Htr1aa, Htr3a, Htr3b, Htr6 genes was revealed (Table 4). There were four types of age-dependent alterations in gene expression: (1) no statistically significant alteration (Tph1a, Htr1b, Htr1f, Htr2cl1, Htr5ab, Htr7); (2) age-dependent increase (Mao); (3) age-dependent decrease 
(Htr1aa, Htr4); and (4) increase at the age of four months followed by a decrease at the age of six months (Tph1b, Tph2, Slc6a4b, Htr2a, Htr3a, Htr3b, Htr6) (Table 5).

Table 5. mRNA level of Tph1a, Tph1b, Tph2, Slc6a4b, Mao, Htr1aa, Htr1b, Htr1f, Htr2a, Htr2cl1, Htr3a, Htr3b, Htr4, Htr5ab, Htr6, and Htr7 genes in the brains of two-, four- and six-month-old males and females of N. furzeri.

\begin{tabular}{|c|c|c|c|c|c|c|}
\hline \multirow{2}{*}{$\begin{array}{l}\text { Age } \\
\text { Sex }\end{array}$} & \multicolumn{2}{|c|}{2 Months of Age } & \multicolumn{2}{|c|}{4 Months of Age } & \multicolumn{2}{|c|}{6 Months of Age } \\
\hline & Male (11) & Female(8) & Male (12) & Female (9) & Male (12) & Female (8) \\
\hline Tph1a & $102.3 \pm 3.4$ & $80.9 \pm 12^{\#}$ & $96.2 \pm 6.8$ & $74.9 \pm 5.3^{\#}$ & $106.0 \pm 7.5$ & $73.0 \pm 8.3^{\# \#}$ \\
\hline Tph1b & $11.1 \pm 1.8$ & $2.7 \pm 0.5^{\#}$ & $21.6 \pm 3.0^{* *}$ & $3.1 \pm 0.5^{\# \# \# ~}$ & $8.4 \pm 2.6^{\$ \$ \$}$ & $4.1 \pm 1.1$ \\
\hline Tph2 & $15.4 \pm 1.6$ & $14.0 \pm 0.9$ & $24.0 \pm 2.4^{* * *}$ & $11.2 \pm 0.7^{\# \# \#}$ & $16.6 \pm 1.9^{\$ \$}$ & $11.0 \pm 0.7^{\#}$ \\
\hline Mao & $112.0 \pm 5.2$ & $106.4 \pm 4.1$ & $129.3 \pm 5.1 *$ & $125.0 \pm 4.8^{\&}$ & $135.5 \pm 5.2^{* *}$ & $128.9 \pm 7.1^{\& \&}$ \\
\hline Slc6a4b & $12.6 \pm 1.5$ & $5.4 \pm 0.6^{\#}$ & $22.5 \pm 3.6^{* *}$ & $5.7 \pm 0.5^{\# \# \#}$ & $10.6 \pm 2.2^{\$ \$}$ & $7.7 \pm 1.3$ \\
\hline Htr1aa & $64.3 \pm 2.5$ & $66.0 \pm 2.2$ & $68.8 \pm 3.3$ & $51.7 \pm 2.3^{\# \#, \& \&}$ & $50.2 \pm 2.4^{* *, \$ \$}$ & $49.4 \pm 3.2^{\& \& \&}$ \\
\hline Htr1b & $27.5 \pm 2.7$ & $29.1 \pm 2.4$ & $35.6 \pm 3.3$ & $30.0 \pm 1.6$ & $27.7 \pm 1.6$ & $28.4 \pm 1.9$ \\
\hline Htr1f & $77.6 \pm 7.0$ & $81.0 \pm 10.5$ & $86.4 \pm 7.3$ & $72.0 \pm 3.9$ & $79.4 \pm 3.8$ & $74.0 \pm 7.9$ \\
\hline Htr2a & $62.7 \pm 2.1$ & $75.3 \pm 3.9 \#$ & $77.3 \pm 2.1^{* * *}$ & $72.9 \pm 3.6$ & $63.2 \pm 2.4^{\$ \$ \$}$ & $72.8 \pm 5.7^{\#}$ \\
\hline Htr2cl1 & $81.7 \pm 3.5$ & $87.3 \pm 5.9$ & $88.9 \pm 4.9$ & $78.8 \pm 3.4$ & $76.2 \pm 3.1$ & $76.8 \pm 4.1$ \\
\hline Htr $3 a$ & $21.3 \pm 2.7$ & $13.9 \pm 1.6$ & $44.0 \pm 6.7^{* * *}$ & $12.6 \pm 0.9^{\# \# \#}$ & $24.1 \pm 5.0^{\$ \$ \$}$ & $13.7 \pm 1.4$ \#\#\# \\
\hline$H t r 3 b$ & $13.5 \pm 2.3$ & $4.3 \pm 0.9^{\#}$ & $26.7 \pm 4.8^{* *}$ & $4.9 \pm 0.8^{\# \# \# ~}$ & $9.3 \pm 2.8^{\$ \$ \$}$ & $4.6 \pm 0.7$ \\
\hline Htr4 & $35.1 \pm 1.7$ & $32.7 \pm 1.9$ & $39.2 \pm 3.4$ & $25.2 \pm 2.7^{\# \# \#}$ & $29.7 \pm 2.1^{\$ \$}$ & $26.2 \pm 1.5$ \\
\hline Htr5ab & $45.3 \pm 1.3$ & $50.1 \pm 1.8$ & $55.3 \pm 3.4$ & $46.1 \pm 2.1$ & $46.8 \pm 2.5$ & $45.6 \pm 2.8$ \\
\hline Htr6 & $15.0 \pm 1.8$ & $9.0 \pm 1.6$ & $26.9 \pm 4.2^{* * *}$ & $13.0 \pm 0.6$ & $16.3 \pm 2.1^{\$ \$}$ & $11.6 \pm 1.9$ \\
\hline Htr7 & $31.4 \pm 3.4$ & $33.1 \pm 3.0$ & $41.1 \pm 3.5$ & $35.2 \pm 1.4$ & $37.5 \pm 2.1$ & $35.2 \pm 2.0$ \\
\hline
\end{tabular}

The data are presented as copies number of target gene/100 copies of Polr2e gene (internal standard). ${ }^{*} p<0.05,{ }^{* *} p<0.01,{ }^{* * *} p<0.01 \mathrm{vs}$.

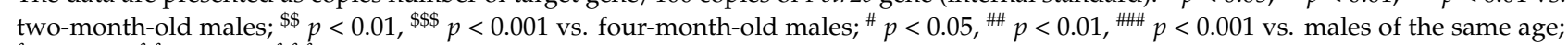
$\& p<0.05$, \&\& $p<0.01$, \&\&\& $p<0.01$ vs. two-month-old females.

The levels of mRNA of Mao and Htr1aa genes gradually increased and decreased, respectively, with age in both males and females (Table 5). No difference in the mRNA level of Htr4 gene in two- and four-month-old males was observed, but this trait decreased in six-month-old males. At the same time, no age-dependent difference in the Htr4 gene mRNA level in females was found (Table 5).

The levels of mRNA of Tph1b, Tph2, Slc6a4b, Htr2a, Htr3b, Htr6 genes increased in fourmonth-old males compared to two- and six-months-old ones. However, no age-dependent alteration in these genes' mRNA levels was observed in the brain of females (Table 5).

No sexual dimorphism for mRNA levels of Mao, Htr1b, Htr1f, Htr2cl1, Htr5ab, or Htr7 genes was observed. At the same time, a significant effect of the "Sex" factor on the mRNA level of Tph1a, Tph1b, Tph2, Slc6a4b, Htr1aa, 5-HT2a, Htr3a, Htr3b, Htr4, and Htr6 genes was revealed (Table 4). The sexual dimorphism was dependent on the gene and age. Tph1a gene mRNA concentration in males was higher compared to females for all age groups. Tph 2 and Htr3a genes mRNA levels in the four- and six-months-old males was higher compared to females of the same age. The mRNA levels of Tph1b, Slc6a4b and the Htr3b genes were higher in two- and four-month-old males than in females of the same age. A significant decrease in Htrlaa, Htr4 and Htr6 genes mRNA concentrations was observed in four-month-old females compared to males of the same age. At the same time, the mRNA level of the Htr2a gene was higher in the brain of two- and six-month-old females compared to males of the same age. No age-dependent dynamics in Tph1b, Tph2, Slc6a4b, Htr1aa, 5-HT2a, Htr3a, Htr3b, Htr4, or the Htr6 genes expression in female brains was shown.

Principal component analysis revealed that $82.5 \%$ variability in the levels of 15 transcripts in the brains of males could be described by three factors. The first factor correlated with Tph1b, Tph2, Slc6a4b, Htr1aa, Htr1b, Htr1f, Htr2cl1, Htr3a, Htr3b, Htr4, Htr5ab and Htr6 genes expression. It reflects the decrease in these genes' expression in 6-month-old males and we named it age-related decrease (Table 6, Figure 4). The second one correlates with $M a o$ and Htr7 genes expressions. It reflects increase in these genes' expression in six-monthold males and we named it "age-related increase" (Table 6, Figure 4). The third factors correlated with the Tph1a gene expression (Table 6). The three-factors model revealed a 
significant effect of age on behavior in males $\left(\mathrm{F}_{6,58}=7.44, p<0.0001\right)$. Discriminant analysis revealed a difference in the genes expression between two- and four- $(p=0.0067)$, two- and six- $(p=0.0005)$, four- and six- $(p=0.0001)$ month-old males (Figure 4$)$. Age-dependent alterations in the first $\left(\mathrm{F}_{3,29}=10.85, p=0.0003\right)$, second $\left(\mathrm{F}_{3,29}=8.57, p=0.0012\right)$ and third $\left(\mathrm{F}_{3,29}=3.66, p=0.038\right)$ factors were revealed.

Table 6. Factor loadings for mRNA levels of Tph1a, Tph1b, Tph2, Slc6a4b, Mao, Htr1aa, Htr1b, Htr1f, Htr2a, Htr2cl1, Htr3b, Htr4, Htr5ab, Htr6, and Htr7 genes in the brain of two-, four- and six-month-old males of $N$. furzeri.

\begin{tabular}{cccc}
\hline Gene & Factor $\mathbf{1}$ (56.3\%) & Factor $\mathbf{2}(\mathbf{1 7 . 3} \%)$ & Factor $\mathbf{3} \mathbf{( 8 . 9 \% )}$ \\
\hline Tph1a & $\mathrm{r}=0.053, p>0.05$ & $\mathrm{r}=0.051, p>0.05$ & $\mathrm{r}=\mathbf{0 . 9 1 ,} \boldsymbol{p}<\mathbf{0 . 0 0 0 1}$ \\
Tph1b & $\mathbf{r}=\mathbf{0 . 9 5 ,} \boldsymbol{p}<\mathbf{0 . 0 0 0 1}$ & $\mathrm{r}=0.20, p>0.05$ & $\mathrm{r}=0.07, p>0.05$ \\
Tph2 & $\mathbf{r}=\mathbf{0 . 8 5 ,} \boldsymbol{p}<\mathbf{0 . 0 0 0 1}$ & $\mathrm{r}=0.39, p>0.05$ & $\mathrm{r}=0.06, p>0.05$ \\
Mao & $\mathrm{r}=0.11, p>0.05$ & $\mathbf{r}=\mathbf{0 . 9 3 ,} \boldsymbol{p}<\mathbf{0 . 0 0 0 1}$ & $\mathrm{r}=0.06, p>0.05$ \\
Slc6a4b & $\mathbf{r}=\mathbf{0 . 9 3 ,} \boldsymbol{p}<\mathbf{0 . 0 0 0 1}$ & $\mathrm{r}=0.23, p>0.05$ & $\mathrm{r}=0.02, p>0.05$ \\
Htr1aa & $\mathbf{r}=\mathbf{0 . 8 3 ,} \boldsymbol{p}<\mathbf{0 . 0 0 0 1}$ & $\mathrm{r}=0.02, p>0.05$ & $\mathrm{r}=-0.14, p>0.05$ \\
Htr1b & $\mathbf{r}=\mathbf{0 . 6 4 ,} \boldsymbol{p}<\mathbf{0 . 0 1}$ & $\mathrm{r}=0.32, p>0.05$ & $\mathrm{r}=0.35, p>0.05$ \\
Htr1f & $\mathbf{r}=\mathbf{0 . 6 5 ,} \boldsymbol{p}<\mathbf{0 . 0 1}$ & $\mathrm{r}=0.39, p>0.05$ & $\mathrm{r}=0.41, p>0.05$ \\
Htr2a & $\mathrm{r}=0.53, p>0.05$ & $\mathrm{r}=0.54, p>0.05$ & $\mathrm{r}=-0.36, p>0.05$ \\
Htr2cl1 & $\mathbf{r}=\mathbf{0 . 8 2 ,} \boldsymbol{p}<\mathbf{0 . 0 0 0 1}$ & $\mathrm{r}=0.34, p>0.05$ & $\mathrm{r}=0.15, p>0.05$ \\
Htr3a & $\mathbf{r}=\mathbf{0 . 8 8 ,} \boldsymbol{p}<\mathbf{0 . 0 0 0 1}$ & $\mathrm{r}=0.35, p>0.05$ & $\mathrm{r}=0.10, p>0.05$ \\
Htr3b & $\mathbf{r}=\mathbf{0 . 9 0 ,} \boldsymbol{p}<\mathbf{0 . 0 0 0 1}$ & $\mathrm{r}=0.12, p>0.05$ & $\mathrm{r}=0.09, p>0.05$ \\
Htr4 & $\mathbf{r}=\mathbf{0 . 8 7}, \boldsymbol{p}<\mathbf{0 . 0 0 0 1}$ & $\mathrm{r}=0.26, p>0.05$ & $\mathrm{r}=0.09, p>0.05$ \\
Htr5ab & $\mathbf{r}=\mathbf{0 . 8 1 ,} \boldsymbol{p}<\mathbf{0 . 0 0 0 1}$ & $\mathrm{r}=0.43, p>0.05$ & $\mathrm{r}=0.05, p>0.05$ \\
Htr6 & $\mathbf{r}=\mathbf{0 . 8 6 ,} \boldsymbol{p}<\mathbf{0 . 0 0 0 1}$ & $\mathrm{r}=0.41, p>0.05$ & $\mathrm{r}=0.13, p>0.05$ \\
Htr7 & $\mathrm{r}=0.53, p>0.05$ & $\mathbf{r}=\mathbf{0 . 6 4 ,} \boldsymbol{p}<\mathbf{0 . 0 1}$ & $\mathrm{r}=0.23, p>0.05$ \\
\hline
\end{tabular}

Statistically significant values are marked in bold.

- $2 \| 4 \Delta 6$ months of age

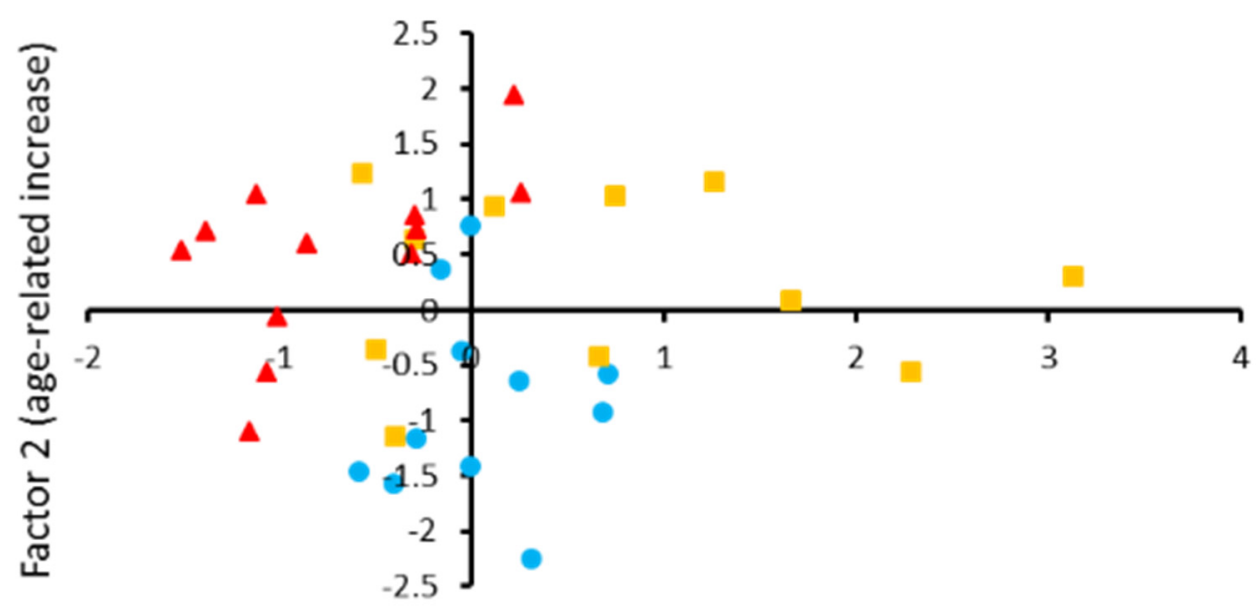

Factor 1 (age-related decrease)

Figure 4. Individual scores for eleven two-month-old, eleven four-month-old and twelve six-monthold males of $N$. furzeri along with factor 1 and factor 2 yielded by the principal component analysis. These factors generalize mRNA levels of 14 of 165 -HT related genes in the brain. Factor 1 loads the genes those expression decreased in old males, such as Tph1a, Tph2, Slc6a4b, Htr1aa, Htr3a, Htr3b, Htr4 and Htr6. Factor 2 loads Mao gene that expression increased in old males. The coordinates of the two axes represent the factor scores of individual animals. Ten of 12 scores corresponding to 6six-month-old males are located in the left half of the graphic. Nine of 11 scores corresponding to two-month-old males are located in the lower half of the graphic. 
3.4. Correlation between Behavioral Traits in Novel Tank Diving Test and mRNA Levels of 5-HT-Related Genes in the Brain of Two-, Four-and Six-Month-Old Males of N. furzeri

No statistically significant correlation between the travelled distance, immobility time, explored part of the tank, distance from the tank's bottom, time spent in the lower and upper thirds in the novel tank diving test on the one hand and the mRNA levels of 16 5-HT related transcripts in the brains on the other hand in two-, four- and six-month-old males was found (Table 7).

Table 7. Correlation between behavioral traits in the novel tank diving test and mRNA levels of 5-HT-related genes in the brain of two-, four- and six-month-old males of N. furzeri.

\begin{tabular}{ccccccc}
\hline Genes & $\begin{array}{c}\text { Travelled } \\
\text { Distance }\end{array}$ & $\begin{array}{c}\text { Immobility } \\
\text { Time }\end{array}$ & $\begin{array}{c}\text { Explored Part } \\
\text { of the Tank }\end{array}$ & $\begin{array}{c}\text { Distance from } \\
\text { the Bottom }\end{array}$ & $\begin{array}{c}\text { Time in the } \\
\text { Lower Third }\end{array}$ & $\begin{array}{c}\text { Time in the } \\
\text { Upper Third }\end{array}$ \\
\hline Tph1a & $-0.11(0.99)$ & $0.04(0.99)$ & $-0.13(0.99)$ & $-0.18(0.99)$ & $0.22(0.99)$ & $-0.13(0.99)$ \\
Tph1b & $-0.27(0.99)$ & $0.26(0.99)$ & $-0.17(0.99)$ & $0.11(0.99)$ & $-0.13(0.99)$ & $0.11(0.99)$ \\
Tph2 & $-0.30(0.99)$ & $0.28(0.99)$ & $-0.24(0.99)$ & $0.08(0.99)$ & $-0.13(0.99)$ & $0.09(0.99)$ \\
Mao & $-0.03(0.99)$ & $-0.05(0.99)$ & $-0.01(0.99)$ & $-0.04(0.99)$ & $0.02(0.99)$ & $-0.02(0.99)$ \\
Stc6a4b & $-0.29(0.99)$ & $0.27(0.99)$ & $-0.18(0.99)$ & $0.08(0.99)$ & $-0.10(0.99)$ & $0.09(0.99)$ \\
Htr1aa & $-0.44(0.75)$ & $0.43(0.78)$ & $-0.19(0.99)$ & $0.28(0.99)$ & $-0.29(0.99)$ & $0.25(0.99)$ \\
Htr1b & $-0.26(0.99)$ & $0.25(0.99)$ & $-0.32(0.99)$ & $-0.16(0.99)$ & $0.13(0.99)$ & $-0.19(0.99)$ \\
Htr1f & $-0.23(0.99)$ & $0.20(0.99)$ & $-0.09(0.99)$ & $0.02(0.99)$ & $-0.02(0.99)$ & $0.03(0.99)$ \\
Htr2a & $-0.40(0.93)$ & $0.38(0.96)$ & $-0.16(0.99)$ & $0.30(0.99)$ & $-0.33(0.99)$ & $0.23(0.99)$ \\
Htr2cl1 & $-0.30(0.99)$ & $0.29(0.99)$ & $-0.29(0.99)$ & $0.01(0.99)$ & $-0.03(0.99)$ & $0.04(0.99)$ \\
Htr3a & $-0.24(0.99)$ & $0.21(0.99)$ & $-0.15(0.99)$ & $0.07(0.99)$ & $-0.10(0.99)$ & $0.07(0.99)$ \\
Htr3b & $-0.40(0.93)$ & $0.38(0.96)$ & $-0.30(0.99)$ & $0.11(0.99)$ & $-0.14(0.99)$ & $0.08(0.99)$ \\
Htr4 & $-0.26(0.99)$ & $0.22(0.99)$ & $-0.02(0.99)$ & $0.31(0.99)$ & $-0.30(0.99)$ & $0.33(0.99)$ \\
Htr5ab & $-0.36(0.98)$ & $0.34(0.99)$ & $-0.14(0.99)$ & $0.19(0.99)$ & $-0.21(0.99)$ & $0.24(0.99)$ \\
Htr6 & $-0.26(0.99)$ & $0.23(0.99)$ & $-0.14(0.99)$ & $0.11(0.99)$ & $-0.13(0.99)$ & $0.10(0.99)$ \\
Htr7 & $-0.23(0.99)$ & $0.18(0.99)$ & $-0.20(0.99)$ & $0.03(0.99)$ & $-0.05(0.99)$ & $0.06(0.99)$ \\
\hline
\end{tabular}

$p$-values (false discovery rate controlled by Bonferroni) are shown in brackets.

\section{Discussion}

In this study we compared the behavior in a novel tank diving test and the levels of mRNA of 5-HT related genes in the brain in three age groups of killifish: (1) relatively young (two months old); (2) middle aged (four months old); and (3) old (6sixmonths old) when natural death of fish begins to occur [12-14]. First of all, we found that males were heavier than females of the same age. This result confirms earlier obtained data $[15,18,20,31,32]$. Body masses of males progressively increased with age and old males were significantly heavier than young ones. However, age-dependent increase in body masses in females was less intensive than those of males. Thus, we did not observe any difference between young, middle aged and old females.

Turquoise killifish is a promising model species for neuroscience, psychopharmacology and ecotoxicology [18,19,31-35]. Behavioral variation in males and females of killifish was shown in the emergence, open field, habitat choice, life skill tests [33] and diurnal activity [34]. However, no sexual dimorphism in killifish behavior in open field, habitat choice and life skill tests was revealed [33]. Earlier we did not find difference in locomotorand anxiety-related traits between males and females of $N$. furzeri [20]. However, in the present study we reveled an increase of immobility time in four-month-old males compared to females of the same age.

A marked decline in spontaneous, exploratory activities [15] and impaired learning performance $[16,17]$ in old N. furzeri were shown. In the present study, significant agerelated alterations in distance travelled and immobility time in males, but not in females were shown. Males of the middle aged group (four-months-old) travelled less distance and were more immobile compared to males from the old group. Principal component analysis of six behavioral parameters in males confirmed this conclusion and showed agerelated variability in the factor associated with locomotor activity. The observed increase in locomotor activity in old males compared to middle aged males seems paradoxical since 
decrease in locomotor activity in aged N. furzeri is well established [15]. We think that the main cause of this paradoxical increase of locomotion is the reduction of the freezing reaction to novelty in old compared to middle aged males: immobility, an index of freezing, in old males was lower than in middle aged males.

Currently, the key role of the brain's 5-HT system in the regulation of behavior in the novel tank diving test in zebrafish is beyond doubt [24]. Indeed, $5-\mathrm{HT}_{1 \mathrm{~A}}$ receptor agonists decrease the time spent near the tank's bottom [36] and 5-HT reuptake blockers cause so called "surface dwelling" [27,36-38]. The brain's 5-HT system also regulates the physiological functions and behavior of killifish: chronic treatment with small doses of 5-HT the transporter inhibitor fluoxetine decreased body size as well as increased fecundity and sociability in N. furzeri $[18,19]$. Moreover, chronic fluoxetine administration reduced travelled distance and total moving time in killifish [34].

The brain's 5-HT system is highly conservative in all vertebrates from fish to mammals [39]. The bodies of 5-HT neurons are mapped in the midbrain while their endings are found in all brain regions [34]. The key enzymes of 5-HT synthesis in mammals are tryptophan hydroxylase 2 (TPH2) in neurons and tryptophan hydroxylase 1 (TPH1) in peripheral tissues those hydroxylate essential amino acid L-tryptophan to 5hydroxytryptophan $[39,40]$. Unlike mammals, in the genome of N. furzeri Tph2, Tph1a and Tph $1 b$ genes are found (Table 8). The synthesized 5-HT is stored in vesicles, transported to 5-HT endings, secreted into the synaptic cleft and then it interacts with numerous 5-HT receptors. Fourteen different subtypes of 5-HT receptors coupled to $\mathrm{G}_{\mathrm{i}}(5-\mathrm{HT} 1 \mathrm{~A}, 5-\mathrm{HT} 1 \mathrm{~B}$, 5-HT1D, 5-HT1E, 5-HT1F, 5-HT5A and 5-HT5B), Gq (5-HT2A, 5-HT2B, 5-HT2C), G (5-HT4, 5-HT6, 5-HT7) proteins or $\mathrm{Na}^{+}$ion-gated channels (5-HT3) are found in the brain of mammals [41,42]. At the same time, in the genome of N. furzeri, only 10 genes (Htr1aa, Htr1b, Htr1f, Htr5ab, Htr2a, Htr2cl1, Htr3, Htr4, Htr6, and Ht7) encoding 5-HT receptors were found (Table 8). Protein 5-HT transporter (SERT) reuptakes 5-HT from the synaptic cleft into 5-HT neurons [43] where it is restored in vesicles or is oxidized to 5-hydroxyindole acetic acid by monoamine oxidase A and B enzymes (MAOA, MAOB) [44,45]. In the genome of $N$. furzeri Scl6a4b gene encodes SERT and the only Mao gene encodes the only enzyme MAO (Table 8).

Table 8. Location of 5-HT related genes in the genome of $N$. furzeri.

\begin{tabular}{ccc}
\hline N. furzeri Gene & Location (Ensemble) & Mammalian Homologue \\
\hline Tph1a & sgr13: 18,976,907-18,981,171 & TPH1 \\
Tph1b & sgr07: 45,615,830-45,638,187 & TPH1 \\
Tph2 & sgr13: 36,218,596-36,239,915 & TPH2 \\
Mao & sgr14: 7,478,504-7,513,691 & MAOA, MAOB \\
Slc6a4b & sgr18: $22,023,293-22,030,954$ & 5-HT transporter \\
Htr1aa & sgr18: 29,466,111-29,467,391 & 5-HT1A \\
Htr1b & sgr04: 71,348,837-71,349,973 & 5-HT1B \\
Htr1f & sgr14: 3,149,799-3,151,013 & 5-HT1F \\
Htr2a & sgr14: 12,123,202-12,202,559 & 5-HT2C \\
Htr2cl1 & sgr04: 14,685,800-14,729,671 & 5-HT3A \\
Htr3a & sgr11: 48,000,514-48,007,311 & 5-HT3B \\
Htr3b & sgr11: 48,010,172-48,020,735 & 5-HT4 \\
Htr4 & sgr01: 53,960,781-54,173,488 & 5-HT5B \\
Htr5ab & sgr08: 18,341,119-18,361,475 & 5-HT6 \\
Htr6 & sgr15: 33,021,207-33,028,620 & 5-HT7 \\
\hline
\end{tabular}

Here we found that Tph1a and Tph1b mRNA levels in brain of males and females of $N$. furzeri are even higher than Tph2. It should be mentioned that data concerning TPH1 expression in the brain are rather contradictory: some authors reported an extremely low Tph1 mRNA level in rat brains [46,47], while other authors found relatively high Tph1 gene expression in rat $[48,49]$ and human [50-52] brains. 
In this research we investigated the effects of sex and age on fifteen 5-HT related genes in the brains of $N$. furzeri for the first time.

First of all, we showed marked sexual dimorphism in Tph1a, Tph1b, Tph2, Slc6a4b, Htr1aa, Htr3a, Htr3b, Htr4, and Htr6 genes expression. The mRNA levels of these genes are higher in middle aged males compared to females of the same age. The cause of this dimorphism is unknown. Moreover, middle aged males and females did not differ in the levels of 5-HT and 5-HIAA in their brains [20].

It should be noted that in males, age-related alterations were shown for expression of 10 genes, Tph1b, Tph2, Mao, Slc6a4b, Htr1aa, Htr2a, Htr3a, Htr3b, Htr4, and Htr6, while in females -this only occurred only for two genes, Mao and Htr1aa.

We showed biphasic dynamics of the Tph2 mRNA level in brains of killifish males: it rose in middle aged males and then again fell in old fish. Age-dependent alterations of $\mathrm{TPH} 2$ in the mammalian brain are obscure. Some authors did not find any difference in the Tph2 mRNA level in the brain structures between young and old rats [53]. However, other authors reported increases and decreases of TPH 2 activity in the midbrain and medulla, respectively, of old rats compared to middle aged ones [54].

A progressive elevation of the Mao transcript level in brains of middle aged and old males and females compared to young killifish was revealed. This result agrees well with elevation of the MAOA activity in the brains of rats [55] and humans [56-58] during aging.

We showed a biphasic dynamic of the Slc6a4b mRNA level in brains of killifish males: it rose in middle aged males and then again fell in older animals. This dynamic agrees with the drop of the SERT protein level in old mice [59], rats [60], hamsters [61] and humans [62].

If TPH2, MAO and SERT seem to play similar functions in killifish and mammals; there is no knowledge about functions of 5-HT receptors in killifish. Here we studied the levels of mRNA of 10 sequenced 5-HT receptor-like genes in the killifish brain. These genes can be conditionally divided into three groups, with high (Htr1aa, Htr1f, Htr2a, Htr2cl1), medium (Htr1b, Htr4, Htr5ab, Htr7) and low (Htr3a, Htr3b, Htr6) expression in the killifish's brain. This distribution of different types of 5-HT receptors in killifish brain is in good concordance with that of the mammalian brain [41].

The level of mRNA of Htr1aa gene encoding the 5-HT1A receptor progressively decreased in brains of old males and females of $N$. furzeri. Some authors also reported the reduction of 5-HT1A binding sites in brains of old rats [63], hamsters [61], monkeys [64] and humans $[65,66]$. However, other investigators did not find any difference in the Htr1a gene mRNA level in brains of young and old rats $[53,67]$.

$H$ tr $2 a$ gene expression in the brain of old males was lower than in middle aged males. Some authors also reported age-dependent reduction of 5-HT2A receptor binding sites in brains of old rats [68], monkeys [64] and humans [66,69]. However, other authors did not find any difference in the Htr2a gene mRNA in brains of young and old rats [67].

The age-dependent decline in the mRNA levels of Htr4 and Htr6 genes in the brain of N. furzeri males shown in our study is in good concordance with that in the 5-HT4 [70] and 5-HT6 $[69,71]$ binding sites in brains of aged humans.

The absence of age-dependent dynamics of Htr 7 mRNA concentration in the brains of $N$. furzeri agrees with that in brains of hamsters [72] and rats [67].

We did not reveal age-related alterations in the level of $H t r 1 b$ gene mRNA in brains of N. males and females. However, other investigators showed decline in 5-HT1B binding sites [69] and the Htr1b mRNA level [53] in brains of old rats compared to young animals.

We did not find published information concerning the age-dependent dynamics of 5HT1F, 5-HT5 and 5-HT3 genes or protein expression in vertebrates. Here, we did not observe any sex and age-dependent alterations in the levels of the Htrif and Htr5ab gene mRNA in killifish brains. At the same time, the brain levels of Htr3a and Htr3b mRNA significantly increased in four-month-old males and then again decreased in six-month-old fish.

Principal component analysis revealed three patterns (factors) of age-dependent alteration in the gene expression in killifish males. The first pattern reflects an age-dependent decline of Tph1b, Tph2, Slc6a4b, Htr1aa, Htr3a, Htr3b, Htr4, and Htr6 gene expression. The 
second pattern reflects an age-dependent elevation of mRNA levels of Mao gene expression. Since MAO is linked to the mitochondrial membrane, this factor can be associated with the age-dependent dysfunction of these organelles. The third pattern correlates with Tph1a gene expression. A biological sense of this factor is still unknown, since there is no information about the role that TPH1A plays in brain of $N$. furzeri.

Although there is pharmacological evidence that 5-HT regulates locomotor activity in $N$. furzeri $[18,19,34]$, in the present study we failed to show any statistically significant correlation between the expression of sixteen 5-HT-related transcripts and the locomotor activity in the novel diving test in killifish males. However, the age-dependent alterations in locomotion could be correlated with those of 5-HT related gene expression in the brain regions involved in the regulation of locomotor activity.

\section{Conclusions}

This is the first study on the effects of sex and age on the 5-HT system and 5-HTdependent behavior in the brain in the novel tank diving test in short-lived turquoise killifish (N. furzeri).

We found the following effect of aging on locomotion in the novel tank diving test in $N$. furzeri males: immobility (freezing) as a reaction to novelty increased in middle aged males and then again decreased in old males, while females did not show any age-related alterations in locomotion in this test.

Selective probes for qPCR quantification were developed and the expression of Tph1a, Tph1b, Tph2, Slc6a4b, Mao, Htr1aa, Htr1b, Htr1f, Htr2a, Htr2cl1, Htr3a, Htr3b, Htr4, Htr5ab, $H t r 6$, and Htr7 in the brains of young (two-month-old), middle aged (four-month-old) and old (six-month old) males and females of $N$. furzeri were studied.

Despite the fact that, due to methodical limitations, we could measure the expression of 5-HT related genes only in the whole brain, we revealed significant sexual and agerelated changes in the expression of some of these genes.

Remarkable sexual dimorphism in Tph1a, Tph1b, Tph2, Slc6a4b, Htr1aa, Htr3a, Htr3b, Htr4, and Htr6 gene expression was shown: their expressions in males were higher than in females.

Two important patterns of age-dependent alterations in these genes expression in killifish male brain was revealed: the mRNA levels of Tph1b, Tph2, Slc6a4b, Htr1aa, Htr2a, Htr3a, Htr3b, Htr4 and Htr6 genes decreased, while Mao gene mRNA levels increased in old males. At the same time, age-related alterations in gene expression in the brain of $N$. furzeri females were more modest: we revealed only elevation of the Mao gene mRNA level and reduction of Htr1aa gene expression in old females.

These age-related changes of these 5-HT related gene expression in the brain of $N$. furzeri males demonstrate a marvelous similarity with aging alterations in TPH2 and MAOA activities as well as SERT and 5-HT receptor binding sites in the brains of rats, monkeys and humans (Table 9). Thus, the observed age-dependent alterations in these 5 -HT related gene alterations in brains of $N$. furzeri indeed reflect the fundamental changes in the vertebrate 5-HT system during aging.

It should be highlighted that six-month-old N. furzeri correspond to 24-month-old rats and mice. Here we have shown that the age-dependent alterations in the brain's 5-HT system in N. furzeri can model the aging changes in the brains of laboratory rodents, monkeys and even humans. Therefore, $N$. furzeri is a promising model species that can significantly accelerate the study of aging effects on the brain's 5-HT system. 
Table 9. Age-related alterations in tryptophan hydroxylases (TPH), monoamine oxidize (MAO), 5-HT transporter (SERT) and 5-HT receptors in the brains of N. furzeri and mammals.

\begin{tabular}{|c|c|c|}
\hline Molecule & N. furzeri (mRNA) & Mammals (Protein, mRNA) \\
\hline $\mathrm{TPH}$ & $\begin{array}{l}\text { Tph1a: } \mathbf{0} \mathrm{m}, \mathrm{f} \\
\text { Tph1b: } \downarrow \mathrm{m}, \mathbf{0} \mathrm{f} \\
T p h 2: \downarrow \mathrm{m}, \mathbf{0} \mathrm{f}\end{array}$ & $\begin{array}{c}\text { Tph2 mRNA: } 0 \text { rat [53]; } \\
\text { TPH2 activity: } \uparrow \text { midbrain } \downarrow \text { medulla rat [54] }\end{array}$ \\
\hline MAO & Mao: $\uparrow \mathrm{m}, \mathrm{f}$ & MAOA activity: $\uparrow$ rat [55], $\uparrow$ human [56-58] \\
\hline SERT & $S l c 6 a 4 b: \downarrow \mathrm{m}, \mathrm{of}$ & $\begin{array}{l}\text { SETR protein: } \downarrow \text { mouse [59], } \downarrow \text { rat [60], } \\
\quad \downarrow \text { hamster [61], } \downarrow \text { human [62] }\end{array}$ \\
\hline 5-HT1A & Htr1aa: $\downarrow \mathrm{m}, \mathrm{f}$ & $\begin{array}{c}\text { 5-HT1A protein: } \downarrow \text { rat }[63], \downarrow \text { hamsters [61], } \\
\downarrow \text { monkey [64], } \downarrow \text { human }[65,66] ; \\
\text { Htr1a mRNA: } 0 \text { rat }[53,62]\end{array}$ \\
\hline 5-HT1B & Htr1b: $0 \mathrm{~m}, \mathrm{f}$ & $\begin{array}{l}\text { 5-HT1B protein: } \downarrow \text { rat [69]; } \\
\text { Htr1b mRNA: } \downarrow \text { rat }[53]\end{array}$ \\
\hline 5-HT1F & Htr1f: $0 \mathrm{~m}, \mathrm{f}$ & No data \\
\hline $5-\mathrm{HT} 2 \mathrm{~A}$ & Htr $2 a: \downarrow \mathrm{m}, \mathbf{0} \mathrm{f}$ & $\begin{array}{c}\text { 5-HT2A protein: } \downarrow \text { rats [64], } \downarrow \text { monkey [64], } \\
\downarrow \text { human }[66,69] ; \\
\text { Htr2a mRNA: } 0 \text { rat }[67]\end{array}$ \\
\hline 5-HT2C & Htr2cl1: $0 \mathrm{~m}, \mathrm{f}$ & Htr2c mRNA: 0 rat [67] \\
\hline $5-\mathrm{HT} 3$ & $\begin{array}{l}H t r 3 a: \downarrow \mathrm{m}, \mathbf{0} \mathrm{f} \\
H t r 3 b: \downarrow \mathrm{m}, \mathbf{0} \mathrm{f}\end{array}$ & No data \\
\hline 5-HT4 & Htru: $\downarrow \mathrm{m}, \mathbf{0} \mathrm{f}$ & 5-HT4 protein: $\downarrow$ human [70] \\
\hline 5-HT5 & Htr5ab: $0 \mathrm{~m}, \mathrm{f}$ & No data \\
\hline 5-HT6 & Htr6: $\downarrow \mathrm{m}, \mathrm{of}$ & 5-HT6 protein: $\downarrow$ human $[69,71]$ \\
\hline 5-HT7 & Htr7: $0 \mathrm{~m}, \mathrm{f}$ & Htr7 mRNA: 0 hamster [72], 0 rat [67] \\
\hline
\end{tabular}

Author Contributions: Conceptualization, A.V.K. and V.S.E.; Methodology, A.V.K. and V.S.E.; Validation, A.V.K., E.A.K. and V.S.E.; Bioinformatics, E.A.K.; Investigation, V.S.E. and E.A.K.; Resources, V.S.E.; Writing-Original Draft Preparation, A.V.K.; Writing-Review \& Editing, V.S.E. and E.A.K.; Project Administration, A.V.K.; Funding Acquisition, A.V.K. All authors have read and agreed to the published version of the manuscript.

Funding: The study was supported by the Russian Science Foundation grant No 21-15-00035. Killifish breeding and rearing was supported by the basic research project No 0259-2021-0015.

Institutional Review Board Statement: The study was conducted in the Department of Genetic Collections of Neural Disorders at the Federal Research Centre Institute of Cytology and Genetics, Siberian Branch of the Russian Academy of Sciences in accordance with the recommendations of the Directive 2010/63/EU of the European Parliament and the Council of 22 September 2010 on the protection of animals used for scientific purposes and was approved by the Committee on the Ethics of Animal Experiments of the Russian National Center of Genetic Resources of Laboratory Animals (protocol No 34 of 15 June 2016). All efforts were made to minimize the suffering of killifish.

Informed Consent Statement: Not applicable.

Data Availability Statement: Not applicable.

Acknowledgments: The authors are grateful to Eugene Berezikov, the group leader of the Laboratory of Stem Cell Regulation and Mechanisms of Regeneration of the European Research Institute of Biology of Ageing (ERIBA, Groningen, the Netherlands) for kindly providing the eggs of N. furzeri. The authors are grateful to Helen Zhorova for assistance in the rearing of $N$. furzeri.

Conflicts of Interest: The authors declare that they have no conflict of interest. 


\section{References}

1. Lesch, K.P.; Waider, J. Serotonin in the modulation of neural plasticity and networks: Implications for neurodevelopmental disorders. Neuron 2012, 76, 175-191. [CrossRef] [PubMed]

2. Lucki, I. The spectrum of behavior influenced by serotonin. Biol. Psychiatry 1998, 44, 151-162. [CrossRef]

3. Maes, M.; Meltzer, H.Y. The serotonin hypothesis of major depression. In Psychopharmacology. The Fourth Generation of Progress; Bloom, E.E., Kupfer, N.N., Eds.; Raven Press: New York, NY, USA, 1995; pp. 933-944.

4. Van Praag, H.M. Can stress cause depression? Prog. Neuropsychopharmacol. Biol. Psychiatry 2004, 28, 891-907. [CrossRef] [PubMed]

5. Willner, P.; Scheel-Krüger, J.; Belzung, C. The neurobiology of depression and antidepressant action. Neurosci. Biobehav. Rev. 2013, 37 Pt 1, 2331-2371. [CrossRef] [PubMed]

6. Hamon, M.; Blier, P. Monoamine neurocircuitry in depression and strategies for new treatments. Prog. Neuropsychopharmacol. Biol. Psychiatry 2013, 45, 54-63. [CrossRef]

7. Miller, B.R.; Hen, R. The current state of the neurogenic theory of depression and anxiety. Curr. Opin. Neurobiol. 2015, 30, 51-58. [CrossRef]

8. Felice, D.; O’Leary, O.F.; Cryan, J.F.; Dinan, T.G.; Gardier, A.M.; Sánchez, C.; David, D.J. When ageing meets the blues: Are current antidepressants effective in depressed aged patients? Neurosci. Biobehav. Rev. 2015, 55, 478-497. [CrossRef]

9. Buhot, M.C.; Martin, S.; Segu, L. Role of serotonin in memory impairment. Ann. Med. 2000, 32, 210-221. [CrossRef]

10. Fidalgo, S.; Ivanov, D.K.; Wood, S.H. Serotonin: From top to bottom. Biogerontology 2013, 14, 21-45. [CrossRef]

11. Kuo, C.Y.; Lin, C.H.; Lane, H.Y. Molecular Basis of Late-Life Depression. Int. J. Mol. Sci. 2021, 22, 7421. [CrossRef]

12. Cellerino, A.; Valenzano, D.R.; Reichard, M. From the bush to the bench: The annual Nothobranchius fishes as a new model system in biology. Biol. Rev. Camb. Philos. Soc. 2016, 91, 511-533. [CrossRef]

13. Terzibasi, E.; Valenzano, D.R.; Cellerino, A. The short-lived fish Nothobranchius furzeri as a new model system for aging studies. Exp. Gerontol. 2007, 42, 81-89. [CrossRef]

14. Platzer, M.; Englert, C. Nothobranchius furzeri: A model for aging research and more. Trends Genet. 2016, 32, 543-552. [CrossRef]

15. Genade, T.; Benedetti, M.; Terzibasi, E.; Roncaglia, P.; Valenzano, D.R.; Cattaneo, A.; Cellerino, A. Annual fishes of the genus Nothobranchius as a model system for aging research. Aging. Cell 2005, 4, 223-233. [CrossRef]

16. Valenzano, D.R.; Terzibasi, E.; Genade, T.; Cattaneo, A.; Domenici, L.; Cellerino, A. Resveratrol prolongs lifespan and retards the onset of age-related markers in a short-lived vertebrate. Curr. Biol. 2006, 16, 296-300. [CrossRef] [PubMed]

17. Terzibasi, E.; Valenzano, D.R.; Benedetti, M.; Roncaglia, P.; Cattaneo, A.; Domenici, L.; Cellerino, A. Large differences in aging phenotype between strains of the shortlived annual fish Nothobranchius furzeri. PLoS ONE 2008, 3, e3866. [CrossRef] [PubMed]

18. Thoré, E.S.J.; Philippe, C.; Brendonck, L.; Pinceel, T. Antidepressant exposure reduces body size, increases fecundity and alters social behavior in the short-lived killifish Nothobranchius furzeri. Environ. Pollut. 2020, 265 Pt A, 115068. [CrossRef]

19. Thoré, E.S.J.; Steenaerts, L.; Philippe, C.; Grégoir, A.F.; Brendonck, L.; Pinceel, T. Improving the reliability and ecological validity of pharmaceutical risk assessment: Turquoise killifish (Nothobranchius furzeri) as a model in behavioral ecotoxicology. Environ. Toxicol Chem. 2019, 38, 262-270. [CrossRef]

20. Evsiukova, V.; Antonov, E.; Kulikov, A.V. Effects of Sex and Group Size on Behavior and Brain Biogenic Amines in Short-Lived Turquoise Killifish (Nothobranchius furzeri). Zebrafish 2021, 18, 265-273. [CrossRef]

21. Gaspar, P.; Lillesaar, C. Probing the diversity of serotonin neurons. Philos. Trans. R. Soc. Lond. B Biol. Sci. 2012, 367, 2382-2394. [CrossRef] [PubMed]

22. Stewart, A.M.; Braubach, O.; Spitsbergen, J.; Gerlai, R.; Kalueff, A.V. Zebrafish models for translational neuroscience research: From tank to bedside. Trends Neurosci. 2014, 37, 264-278. [CrossRef] [PubMed]

23. Kalueff, A.V.; Stewart, A.M.; Gerlai, R. Zebrafish as an emerging model for studying complex brain disorders. Trends Pharmacol. Sci. 2014, 35, 63-75. [CrossRef] [PubMed]

24. Herculano, A.M.; Maximino, C. Serotonergic modulation of zebrafish behavior: Towards a paradox. Prog. Neuropsychopharmacol. Biol. Psychiatry 2014, 55, 50-66. [CrossRef] [PubMed]

25. Polačik, M.; Blažek, R.; Reichard, M. Laboratory breeding of the short-lived annual killifish Nothobranchius furzeri. Nat. Protoc. 2016, 11, 1396-1413. [CrossRef]

26. Kulikov, A.V.; Tikhonova, M.A.; Kulikov, V.A. Automated measurement of special preference in the open field test with transmitted lighting. J. Neurosci. Meth. 2008, 170, 345-351. [CrossRef]

27. Kulikov, A.V.; Sinyakova, N.A.; Kulikova, E.A.; Khomenko, T.M.; Salakhutdinov, N.F.; Kulikov, V.A.; Volcho, K.P. Effects of acute and chronic treatment of novel psychotropic drug, 8- (trifluoromethyl)-1, 2, 3, 4, 5-benzopentathiepin-6-amine hydrochloride (TC-2153), on the behavior of zebrafish (Danio rerio): A comparison with fluoxetine. Lett. Drug. Des. Discov. 2019, 16, 1321-1328. [CrossRef]

28. Kulikov, V.A.; Khotskin, N.V.; Nikitin, S.V.; Lankin, V.S.; Kulikov, A.V.; Trapezov, O.V. Application of 3-D imaging sensor for tracking minipigs in the open field test. J. Neurosci. Methods 2014, 235, 219-225. [CrossRef]

29. Khotskin, N.V.; Plyusnina, A.V.; Kulikova, E.A.; Bazhenova, E.Y.; Fursenko, D.V.; Sorokin, I.E.; Kolotygin, I.; Mormede, P.; Terenina, E.E.; Shevelev, O.B.; et al. On association of the lethal yellow (AY) mutation in the agouti gene with the alterations in mouse brain and behavior. Behav. Brain Res. 2019, 359, 446-456. [CrossRef] [PubMed] 
30. Kulikova, E.A.; Fursenko, D.V.; Bazhenova, E.Y.; Kulikov, A.V. Decrease in the Activity of Striatal-enriched Protein-tyrosinePhosphatase (STEP) in the Brain of Danio rerio Treated with $p$-Chlorophenylalanine and Pargyline. Mol. Biol. 2021, 55, 573-578. [CrossRef]

31. Thoré, E.S.J.; Grégoir, A.F.; Adriaenssens, B.; Philippe, C.; Stoks, R.; Brendonck, L.; Pinceel, T. Population-, sex- and individual level divergence in life-history and activity patterns in an annual killifish. PeerJ 2019, 7, e7177. [CrossRef]

32. Thoré, E.S.J.; Brendonck, L.; Pinceel, T. Conspecific density and environmental complexity impact behaviour of turquoise killifish (Nothobranchius furzeri). J. Fish. Biol. 2020, 97, 1448-1461. [CrossRef] [PubMed]

33. Thoré, E.S.J.; Steenaerts, L.; Philippe, C.; Grégoir, A.; Brendonck, L.; Pinceel, T. Individual behavioral variation reflects personality divergence in the upcoming model organism Nothobranchius furzeri. Ecol. Evol. 2018, 8, 8448-8457. [CrossRef] [PubMed]

34. Thoré, E.S.J.; Brendonck, L.; Pinceel, T. Natural daily patterns in fish behavior may confound results of ecotoxicological testing. Environ. Pollut. 2021, 276, 116738. [CrossRef] [PubMed]

35. Thoré, E.S.J.; Philippe, C.; Brendonck, L.; Pinceel, T. Towards improved fish tests in ecotoxicology-Efficient chronic and multi-generational testing with the killifish Nothobranchius furzeri. Chemosphere 2021, 273, 129697. [CrossRef]

36. Maximino, C.; Puty, B.; Benzecry, R.; Araújo, J.; Lima, M.G.; de Jesus Oliveira Batista, E.; Renata de Matos Oliveira, K.; Crespo-Lopez, M.E.; Herculano, A.M. Role of serotonin in zebrafish (Danio rerio) anxiety: Relationship with serotonin levels, and effect of buspirone, WAY 100635, SB 224289, fluoxetine and parachlorophenylalanine (pCPA) in two behavioral models. Neuropharmacology 2013, 71, 83-97. [CrossRef]

37. Egan, R.J.; Bergner, C.L.; Hart, P.C.; Cachat, J.M.; Canavello, P.R.; Elegante, M.F.; Elkhayat, S.I.; Bartels, B.K.; Tien, A.K.; Tien, D.H.; et al. Understanding behavioral and physiological phenotypes of stress and anxiety in zebrafish. Behav. Brain Res. 2009, 205, 38-44. [CrossRef]

38. Kulikova, E.A.; Bazovkina, D.V.; Evsyukova, V.S.; Kulikov, A.V. Acute Administration of Imipramine and Citalopram Increases Activity of Striatal-Enriched Tyrosine Protein Phosphatase (STEP) in Brain of Zebrafish Danio rerio. Bull. Exp. Biol. Med. 2021, 170, 627-630. [CrossRef]

39. Walther, D.J.; Peter, J.U.; Bashammakh, S.; Hörtnagl, H.; Voits, M.; Fink, H.; Bader, M. Synthesis of serotonin by a second tryptophan hydroxylase isoform. Science 2003, 299, 76. [CrossRef]

40. Walther, D.J.; Bader, M. A unique central tryptophan hydroxylase isoform. Bio. Pharmacol. 2003, 66, 1673-1680. [CrossRef]

41. Barnes, N.M.; Sharp, T. A review of central 5-HT receptors and their function. Neuropharmacology 1999, 38, 1083-1152. [CrossRef]

42. Pytliak, M.; Vargová, V.; Mechírová, V.; Felšöci, M. Serotonin receptors-From molecular biology to clinical applications. Physiol. Res. 2011, 60, 15-25. [CrossRef]

43. Grouleff, J.; Ladefoged, L.K.; Koldsø, H.; Schiøtt, B. Monoamine transporters: Insights from molecular dynamics simulations . Front. Pharmacol. 2015, 6, 235. [CrossRef] [PubMed]

44. Shih, J.C.; Thompson, R.F. Monoamine oxidase in neuropsychiatry and behavior. Am. J. Hum. Genet. 1999, 65, 593-598. [CrossRef] [PubMed]

45. Shih, J.C.; Wu, J.B.; Chen, K. Transcriptional regulation and multiple functions of MAO genes. J. Neural. Transm. 2011, 118, 979-986. [CrossRef] [PubMed]

46. Patel, P.D.; Pontrello, C.; Burke, S. Robust and tissue-specific expression of TPH2 versus TPH1 in rat raphe and pineal gland. Biol. Psychiatry 2004, 55, 428-433. [CrossRef] [PubMed]

47. Sakowski, S.A.; Geddes, T.J.; Thomas, D.M.; Levi, E.; Hatfield, J.S.; Kuhn, D.M. Differential tissue distribution of tryptophan hydroxylase isoforms 1 and 2 as revealed with monospecific antibodies. Brain Res. 2006, 1085, 11-18. [CrossRef]

48. Megha, K.; Deshmukh, P.S.; Ravi, A.K.; Tripathi, A.K.; Abegaonkar, M.P.; Banerjee, B.D. Effect of Low-Intensity Microwave Radiation on Monoamine Neurotransmitters and Their Key Regulating Enzymes in Rat Brain. Cell Biochem. Biophys. 2015, 73, 93-100. [CrossRef]

49. Igarashi, K.; Kuchiiwa, T.; Kuchiiwa, S.; Iwai, H.; Tomita, K.; Sato, T. Kamishoyosan (a Japanese traditional herbal formula), which effectively reduces the aggressive biting behavior of male and female mice, and potential regulation through increase of Tph1, Tph2, and Esr2 mRNA levels. Brain Res. 2021, 1768, 147580. [CrossRef]

50. Zill, P.; Büttner, A.; Eisenmenger, W.; Möller, H.J.; Ackenheil, M.; Bondy, B. Analysis of tryptophan hydroxylase I and II mRNA expression in the human brain: A post-mortem study. J. Psychiatr. Res. 2007, 41, 168-173. [CrossRef]

51. Zill, P.; Büttner, A.; Eisenmenger, W.; Müller, J.; Möller, H.J.; Bondy, B. Predominant expression of tryptophan hydroxylase 1 mRNA in the pituitary: A postmortem study in human brain. Neuroscience 2009, 159, 1274-1282. [CrossRef] [PubMed]

52. Sugden, K.; Tichopad, A.; Khan, N.; Craig, I.W.; D'Souza, U.M. Genes within the serotonergic system are differentially expressed in human brain. BMC Neurosci. 2009, 10, 50. [CrossRef]

53. Mitchell, E.S.; McDevitt, R.A.; Neumaier, J.F. Adaptations in 5-HT receptor expression and function: Implications for treatment of cognitive impairment in aging. J. Neurosci. Res. 2009, 87, 2803-2811. [CrossRef]

54. Hussain, A.M.; Mitra, A.K. Effect of aging on tryptophan hydroxylase in rat brain: Implications on serotonin level. Drug. Metab. Dispos. 2000, 28, 1038-1042. [PubMed]

55. Banerjee, S.; Poddar, M.K. Carnosine: Effect on aging-induced increase in brain regional monoamine oxidase-A activity. Neurosci. Res. 2015, 92, 62-70. [CrossRef] [PubMed]

56. Saura, J.; Andrés, N.; Andrade, C.; Ojuel, J.; Eriksson, K.; Mahy, N. Biphasic and region-specific MAO-B response to aging in normal human brain. Neurobiol. Aging. 1997, 18, 497-507. [CrossRef] 
57. Kumar, M.J.; Andersen, J.K. Perspectives on MAO-B in aging and neurological disease: Where do we go from here? Mol. Neurobiol. 2004, 30, 77-89. [CrossRef]

58. Nicotra, A.; Pierucci, F.; Parvez, H.; Senatori, O. Monoamine oxidase expression during development and aging. Neurotoxicology 2004, 25, 155-165. [CrossRef]

59. Mitchell, N.C.; Gould, G.G.; Koek, W.; Daws, L.C. Ontogeny of SERT Expression and Antidepressant-like Response to Escitalopram in Wild-Type and SERT Mutant Mice. J. Pharmacol. Exp. Ther. 2016, 358, 271-281. [CrossRef]

60. Herrera-Pérez, J.J.; Fernández-Guasti, A.; Martínez-Mota, L. Brain SERT Expression of Male Rats Is Reduced by Aging and Increased by Testosterone Restitution. Neurosci. J. 2013, 201909. [CrossRef] [PubMed]

61. Duncan, M.J.; Hensler, J.G. Aging alters in a region-specific manner serotonin transporter sites and 5-HT(1A) receptor-G protein interactions in hamster brain. Neuropharmacology 2002, 43, 36-44. [CrossRef]

62. van Dyck, C.H.; Malison, R.T.; Seibyl, J.P.; Laruelle, M.; Klumpp, H.; Zoghbi, S.S.; Baldwin, R.M.; Innis, R.B. Age-related decline in central serotonin transporter availability with [(123)I] beta-CIT SPECT. Neurobiol. Aging 2000, 21, 497-501. [CrossRef]

63. Nyakas, C.; Oosterink, B.J.; Keijser, J.; Felszeghy, K.; de Jong, G.I.; Korf, J.; Luiten, P.G. Selective decline of 5-HT1A receptor binding sites in rat cortex, hippocampus and cholinergic basal forebrain nuclei during aging. J. Chem. Neuroanat. 1997, 13, 53-61. [CrossRef]

64. Bigham, M.H.; Lidow, M.S. Adrenergic and serotonergic receptors in aged monkey neocortex. Neurobiol. Aging 1995, 16, 91-104. [CrossRef]

65. Costes, N.; Merlet, I.; Ostrowsky, K.; Faillenot, I.; Lavenne, F.; Zimmer, L.; Ryvlin, P.; Le Bars, D. A 18F-MPPF PET normative database of 5-HT1A receptor binding in men and women over aging. J. Nucl. Med. 2005, 46, 1980-1989. [PubMed]

66. Moses-Kolko, E.L.; Price, J.C.; Shah, N.; Berga, S.; Sereika, S.M.; Fisher, P.M.; Coleman, R.; Becker, C.; Mason, N.S.; Loucks, T.; et al. Age, sex, and reproductive hormone effects on brain serotonin-1A and serotonin-2A receptor binding in a healthy population. Neuropsychopharmacology 2011, 36, 2729-2740. [CrossRef]

67. Yau, J.L.; Olsson, T.; Noble, J.; Seckl, J.R. Serotonin receptor subtype gene expression in the hippocampus of aged rats following chronic amitriptyline treatment. Brain Res. Mol. Brain Res. 1999, 70, 282-287. [CrossRef]

68. Gozlan, H.; Daval, G.; Verge, D.; Spampinato, U.; Fattaccini, C.M.; Gallissot, M.C.; el Mestikawy, S.; Hamon, M. Aging associated changes in serotoninergic and dopaminergic pre- and postsynaptic neurochemical markers in the rat brain. Neurobiol. Aging 1990, 11, 437-449. [CrossRef]

69. Lorke, D.E.; Lu, G.; Cho, E.; Yew, D.T. Serotonin 5-HT2A and 5-HT6 receptors in the prefrontal cortex of Alzheimer and normal aging patients. BMC Neurosci. 2006, 7, 36. [CrossRef]

70. Madsen, K.; Haahr, M.T.; Marner, L.; Keller, S.H.; Baaré, W.F.; Svarer, C.; Hasselbalch, S.G.; Knudsen, G.M. Age and sex effects on 5-HT(4) receptors in the human brain: A [(11)C] SB207145 PET study. J. Cereb. Blood Flow Metab. 2011, 31, 1475-1481. [CrossRef]

71. Radhakrishnan, R.; Nabulsi, N.; Gaiser, E.; Gallezot, J.D.; Henry, S.; Planeta, B.; Lin, S.F.; Ropchan, J.; Williams, W.; Morris, E.; et al. Age-Related Change in 5-HT 6 Receptor Availability in Healthy Male Volunteers Measured with ${ }^{11}$ C-GSK215083 PET. J. Nucl. Med. 2018, 59, 1445-1450. [CrossRef] [PubMed]

72. Duncan, M.J.; Franklin, K.M. Expression of 5-HT7 receptor mRNA in the hamster brain: Effect of aging and association with calbindin-D28K expression. Brain Res. 2007, 1143, 70-77. [CrossRef] [PubMed] 